\title{
SPONTANEOUS CORMOPHYTES FROM THE ROMANIAN FLORA KNOWN AS MEDICINAL PLANTS IN OTHER COUNTRIES
}

\author{
Mihai $\operatorname{COSTICA}{ }^{1 *}$, Anisoara STRATU1 ${ }^{1}$, Naela $\operatorname{COSTICA} \breve{~}^{1}$ \\ ${ }^{1}$ Departament of Biology, Faculty of Biology, “Alexandru Ioan Cuza” University of Iasi, Romania
}

*Correspondence:

Mihai COSTICĂ

costicamihai13@yahoo.ro

Received: 27 November 2021; Accepted: 18 December 2021; Published: 30 December 2021

\begin{abstract}
Romania's medicinal flora is an important source of raw material for pharmacological research and drug production. By consulting the pharmacological literature on authenticated scientific sources such as Google Scholar, 15 species of medicinal plants existing in the Romanian flora, but not used in the traditional Romanian medicine, were identified. In accordance with the World Health Organization's call on all countries to use traditional medicine in primary care, we set out to help complete the list of medicinal plants in Romania using information from traditional medicine in other countries.
\end{abstract}

Keywords: medicinal plants, flora, Romania, foreign countries

\section{Introduction}

From the beginning of the appearance of man on Earth, plants have been used as food, shelter and sources of natural substances prepared for the treatment of diseases that occur during life.

How they discovered medicinal plants? By observing nature, understanding the connections between plants and animals, between climate and plants. Thus, they observed that animals preferred certain species while they were sick, that birds consumed only certain fruits that were edible.

The number of flowering plant species used for medicinal purposes today reached 50,000 out of a total of 422,127 known flowering plant species (Govaert, 2001, Schippman et al., 2002).

Romania has a rich vegetation and flora and is the only country that has 5 of the 11 biogeographical regions of Europe, respectively the steppe, pontic, panonic, continental, alpine region. Of the 3700 spontaneous species in Romania (Ciocârlan, 2009), over 756 species of medicinal plants are identified, of which 126 species are included on the Red List of Superior Plants, and for 122 species the collection is prohibited (Bujorean, 1936; Butura, 1979; Dihoru and Boruz, 2014).

Some of the medicinal species are collected and marketed for the extraction of various types of biologically active substances. Some of these are relatively well known by the inhabitants of Romania, but species with medicinal potential must be identified taxonomically only by botanists.

In accordance with the urging of the World Health Organization to all countries to use traditional medicine in primary care (WHO 
1987), we set out to help complete the list of medicinal plants in Romania using information from traditional medicine of other countries.

The species mentioned in the study are mostly Eurasian phytogeographic element which explains the presence and knowledge of these species as medicinal plants in countries like Iraq, Iran, Bangladesh and India.

\section{Materials and methods}

The existing ethno-pharmaceutical literature was consulted on authenticated scientific sources such as Google Scholar which often provides links to full text PDF file about the medicinal species used by traditional and modern medicine.

The consultation of the literature allowed the identification of the medicinal species used in other countries and existing in the Romanian flora but not used.

\section{Results and discussion}

We specify the species of plants from the Romanian flora that are used in the traditional medicine of other countries but not known as medicinal plants in our country.

There were found 15 species of unused medicinal cormophytes in Romania.

Among these species Amaranthus viridis is rare, Sisymbrium irio is very rare, Pinguicula alpina is sporadic, Ranunculus thora is european endemit.

These species grow in different habitats distributed from the steppe to the alpine meadows, classified in 12 botanical families. The Asteraceae family contains 3 species, the Brassicaceae and Ranunculaceae families contain 2 species and the other families have one species each.

The species mentioned in this study are traditionally used in diseases of the auditory, digestive, respiratory system, nervous system, lipid metabolism, in the elimination of intestinal parasites etc. (Table 1).

Table 1. Cormophytes from the Romanian flora known as medicinal plants in the traditional medicine of other countries

\begin{tabular}{|c|c|c|c|c|c|}
\hline $\begin{array}{l}\text { Current } \\
\text { Nr. }\end{array}$ & $\begin{array}{l}\text { Scientific name; } \\
\text { Vernacular name (Local } \\
\text { name), Family; } \\
\text { phytosociological taxon }\end{array}$ & Part Used & Preparation & $\begin{array}{l}\text { Uses/ailments } \\
\text { ameliorated }\end{array}$ & References \\
\hline 1. & $\begin{array}{l}\text { Allium scorodoprasum; } \\
\text { Aiul şarpelui; } \\
\text { Liliaceae; Prunion } \\
\text { spinosae; Ulmenion }\end{array}$ & $\begin{array}{l}\text { Bulbils and } \\
\text { leaves }\end{array}$ & $\begin{array}{l}\text { Plant is } \\
\text { eaten raw }\end{array}$ & $\begin{array}{l}\text { Antihypertensive, } \\
\text { high cholesterol }\end{array}$ & $\begin{array}{l}\text { Hayta et al., } \\
2014\end{array}$ \\
\hline 2. & $\begin{array}{l}\text { Amaranthus viridis; } \\
\text { Amaranthaceae }\end{array}$ & Whole plant & Potherbs & $\begin{array}{l}\text { Amenorrhoea, } \\
\text { menorrhagia, } \\
\text { haemoptysis, } \\
\text { bleeding ulcer }\end{array}$ & $\begin{array}{l}\text { Qureshi et } \\
\text { al., } 2008\end{array}$ \\
\hline 3. & $\begin{array}{l}\text { Artemisia scoparia; } \\
\text { Pelin de mături; } \\
\text { Asteraceae; Festucion } \\
\text { valesiacae }\end{array}$ & Whole plant & $\begin{array}{l}\text { Decoction } \\
\text { Powdered } \\
\end{array}$ & $\begin{array}{l}\text { Asthma, spasms and } \\
\text { nervous diseases, } \\
\text { jaundice, anti- } \\
\text { inflammatory to } \\
\text { toothache } \\
\text { Skin diseases }\end{array}$ & $\begin{array}{l}\text { Qureshi et } \\
\text { al., } 2008\end{array}$ \\
\hline 4. & $\begin{array}{l}\text { Brasica rapa; } \\
\text { Rapița } \quad \text { Brassicaceae; }\end{array}$ & Seeds & Oil (Warm) & $\begin{array}{l}\text { Applied externally, } \\
\text { ear drop, sciatica }\end{array}$ & $\begin{array}{l}\text { Semwal et } \\
\text { al., } 2010\end{array}$ \\
\hline
\end{tabular}


ABMJ 2021, 4(2): 50-55

\begin{tabular}{|c|c|c|c|c|c|}
\hline & Chenopodietalia albi & & & & \\
\hline 5. & $\begin{array}{l}\text { Carduus nutans L. subsp. } \\
\text { nutans; } \\
\text { Ciulin; } \\
\text { Asteraceae; Onopordion }\end{array}$ & Aerial parts & Infusion & $\begin{array}{l}\text { Sedative, } \\
\text { gastrointestinal } \\
\text { disorders }\end{array}$ & $\begin{array}{l}\text { Hayta et al., } \\
2014\end{array}$ \\
\hline 6. & $\begin{array}{l}\text { Elaeagnus angustifolia; s } \\
\text { Sălcioară; } \\
\text { Elaeagnaceae }\end{array}$ & $\begin{array}{l}\text { Fruit and } \\
\text { seed }\end{array}$ & Powdered & $\begin{array}{l}\text { Diarrhoea and } \\
\text { osteoporosis (oral) }\end{array}$ & $\begin{array}{l}\text { Naghibi et } \\
\text { al., } 2014\end{array}$ \\
\hline 7. & $\begin{array}{l}\text { Falcaria vulgaris; } \\
\text { Dornic; } \\
\text { Apiaceae; } \quad \text { Convolvio- } \\
\text { Agropyrion }\end{array}$ & Leaf & Powdered & Wounds & $\begin{array}{l}\text { Naghibi et } \\
\text { al., } 2014\end{array}$ \\
\hline 8. & $\begin{array}{l}\text { Gentiana acaulis; } \\
\text { Cupe; } \\
\text { Gentianaceae; Potentillo } \\
\text { ternatae-Nardion }\end{array}$ & Roots & Decoction & $\begin{array}{l}\text { Gastrointestinal } \\
\text { disorders }\end{array}$ & $\begin{array}{l}\text { Vitalini et } \\
\text { al., } 2009\end{array}$ \\
\hline 9. & $\begin{array}{l}\text { Oxalis } \quad \text { corniculata } ; \\
\text { Oxalidaceae; } \\
\text { Plantaginion }\end{array}$ & Leaves & Extract & $\begin{array}{l}\text { Open sores, } \\
\text { pimples, skin } \\
\text { disease }\end{array}$ & $\begin{array}{l}\text { Semwal et } \\
\text { al., } 2010\end{array}$ \\
\hline 10. & $\begin{array}{l}\text { Pinguicula alpina; } \\
\text { Lentibulariaceae; } \\
\text { Caricetalia davallianae }\end{array}$ & Leaves & Juice & $\begin{array}{l}\text { External use: } \\
\text { wound, cut healing }\end{array}$ & $\begin{array}{l}\text { Vitalini et } \\
\text { al., } 2009\end{array}$ \\
\hline 11. & $\begin{array}{l}\text { Phlomis herba-venti ssp. } \\
\text { pungens; } \\
\text { Scorogoi; } \\
\text { Lamiaceae; Festucion } \\
\text { valesiacae }\end{array}$ & Aerial parts & Infusion & $\begin{array}{l}\text { Anthelmintic, } \\
\text { stomach-ache }\end{array}$ & $\begin{array}{l}\text { Mirdeilami } \\
\text { et al., } 2011\end{array}$ \\
\hline 12. & $\begin{array}{l}\text { Ranunculus } \\
\text { Ranunculaceae; } \\
\text { Seslerion bielzii }\end{array}$ & Leaves & $\begin{array}{l}\text { Fresh put on } \\
\text { the painful } \\
\text { part }\end{array}$ & $\begin{array}{l}\text { Arthritis, } \\
\text { rheumatism, anti- } \\
\text { inflammatory }\end{array}$ & $\begin{array}{l}\text { Vitalini et } \\
\text { al., } 2009\end{array}$ \\
\hline 13. & $\begin{array}{l}\text { Sisymbrium irio; } \\
\text { Brassicaceae; Sisymbrion }\end{array}$ & $\begin{array}{l}\text { Leaves, } \\
\text { seeds }\end{array}$ & Infusion & $\begin{array}{l}\text { Throat and chest } \\
\text { infections, } \\
\text { expectorant } \\
\text { stimulant and } \\
\text { antiseptic }\end{array}$ & $\begin{array}{l}\text { Qureshi et } \\
\text { al., } 2008\end{array}$ \\
\hline 14. & $\begin{array}{l}\text { Sonchus arvensis; } \\
\text { Asteraceae; } \\
\text { Chenopodietalia albi }\end{array}$ & Whole plant & Infusion & $\begin{array}{l}\text { Cough, bronchitis, } \\
\text { asthma. Phthisis. } \\
\text { jaundice }\end{array}$ & $\begin{array}{l}\text { Qureshi et } \\
\text { al., } 2008\end{array}$ \\
\hline 15. & $\begin{array}{l}\text { Viola biflora; } \\
\text { Toporași galbeni; } \\
\text { Violaceae; } \\
\text { Cystopteridion }\end{array}$ & Fruit & $\begin{array}{l}\text { Capsule } \\
\text { paste }\end{array}$ & $\begin{array}{l}\text { Diaphoretic and } \\
\text { intestinal pain }\end{array}$ & $\begin{array}{l}\text { Semwal et } \\
\text { al., } 2010\end{array}$ \\
\hline
\end{tabular}

In traditional medicine, the use of medicinal plants is based on observations and empirical knowledge. For some of the 15 species mentioned in our list, the medicinal properties are confirmed by laboratory research.

Falcaria vulgaris is a Eurasian phytogeographic element, a segetal, ruderal and frequent species from the plain to the storey of the oak. Powder of Falcaria vulgaris showed gastroprotective effect of against ethanolinduced ulcers (it is a rich source of tannins and ascorbic acid) (Khazaei and Salehi, 2006).

Carduus nutans. subsp. nutans is a Eurasian phytogeographic element, frequent from the plain to the storey of the beech. It is 
used to treat throat cancer (contain significant amount of polyphenols and flavonoids) (Bozyel et al., 2019).

Allium scorodoprasum is a central European phytogeographic element, frequent from the forest-steppe to the storey of the oak. Methanol extract of $A$. scorodoprasum has important antioxidant capacity (contain phenols and flavonoids) (Mitic et al., 2014).

Sisymbrium irio is a Mediterranean phytogeographic element, ruderal species, rare, in the counties of Mures, Alba, Prahova, Vaslui, Neamt, Iasi (Sârbu et al., 2013). Crude extracts of the seeds were tested for antipyretic, analgesic and antimicrobial effects (Hailu et al., 2019)

Amaranthus viridis, rare species identified in Constanta County (Sârbu et al., 2013), adventitious, origin South America. This species has the potential to treat diabetes mellitus and complications owing to its antidiabetic and antihyperlipidemic effect (contain phytoconstituents like steroids, alkaloids, glycosides, flavonoids, carbohydrates, amino acids, proteins and phenolic compounds) (Pandhare et al., 2012).

Viola biflora is a Circumpolar phytogeographic element, frequent from the storey of the beech to the storey of the subalpine. The alpine violet Viola biflora is a rich source of cyclotides. The cyclotides have been shown to be cytotoxic, anti-HIV, antimicrobial and hemolytic agents. (Herrmann et al., 2008)

Oxalis corniculata is a Mediterranean phytogeographic element, a sub spontaneous segetal and ruderal species. It showed activity in cough, scabies, itching, dysentery, anemia, piles, dyspepsia and fever (Rahman et al., 2014)

\section{Conclusions}

From the ethnopharmacological literature of the countries around Romania, close or less close, it was possible to identify species existing in the spontaneous flora of Romania with medicinal qualities in a wide range of diseases according to the traditional medicine.

Our study outlines the useful plant resources beneficial for the health of the inhabitants of our country by completing the list of medicinal plants in Romania.

Medicinal species is an important source of raw materials in pharmacological research and drug production in Romania.

The use of plants in traditional medicine has allowed the accumulation of much information that can be confirmed or refuted by research in specialized laboratories.

\section{Conflict of interest}

The authors declare that there are no conflicts of interest related to this article.

\section{References}

1. Bozyel ME, Merdamert Bozyel E, Canlı K, Altuner EM (2019) Anticancer Uses of Medicinal Plants in Turkish Traditional Medicine. KSU J. Agric Nat. 22(Suppl. 2): pp 465-484.

DOI: 10.18016/ ksutarimdoga.vi.550334

2. Bujorean G (1936) Boli, leacuri și plante de leac cunoscute de țărănimea română. Publ Period a Asoc Astra [Internet]. Editura Asociatiunii Astra Sibiu.;26:1-398 Available from:

http://dspace.bcucluj.ro/handle/123456789/ 68446

3. Butură V (1979) Enciclopedie de etnobotanică românească. București: Editura Științifică și Enciclopedică; 
4. Ciocârlan V (2009) Flora ilustrată a României. Pteridophyta et Spermatophyta. 1141 pp. Edit. Ceres. Bucureşti

5. Dihoru Gheorghe, Boruz Violeta (2014) The list of main spontaneous medicinal plants from Romania, Analele Uniiversităţii din Craiova, seria Agricultură Montanologie - Cadastru (Annalls of the University of Craiova - Agriculture, Montanology, Cadastre Series) Vol.. XLIV

6. Govaert R (2001) How many species of seed plants are there? Taxon 50, pp 10851090

7. Hailu T, Gupta RK, Rani A (2019) Sisymbrium irio L.: A Herb used in the Unani system of medicine for broad spectrum therapeutical applications, Indian Journal of Traditional Knowledge Vol 18(1), pp 140-143

8. Hayta Sukru, Polat Ridvan, Selvi Selami (2014) Traditional uses of medicinal plants in Elazığ (Turkey), Journal of Ethnopharmacology 154 (2014) pp 613623

9. Herrmann A, Myline J, Karlsson G (2008) The alpine violet, Viola biflora, is a rich source of novel cyclotides with potent cytotoxic cytotoxicity, Ohytochemistry, vol 69, no 4, pp 939-952

10. Khazaei Mozafar, Salehi Hossein (2006) Protective Effect of Falcaria vulgaris Extract on Ethanol Induced Gastric Ulcer in Rat, Iranian Journal of Pharmacology and therapeutics (IJPT), vol. 5, no. 1, pp 43-46

11. Mirdeilami Seyedeh Zohreh, Barani Hossein, Mazandarani Masumeh, Heshmati Ali Gholam (2011) Ethnopharmacological Survey of Medicinal Plants in Maraveh Tappeh Region, North of Iran, Iranian Journal of Plant Physiology, 2(1), pp 325 336.

12. Mitic V. D., Stankov-Jovanovic V P, Ilic M D, Cvetkovic J S, Dimitrijevic M V, Stojanovic G S (2014) In vitro antioxidant activity of methanol extract of Allium scorodoprasum, Bulgarian Journal of Agricultural Science, 20, no 5, pp 11301136

13. Naghibi F, Esmaeili S, Malekmohammadi M, Hassanpour A, Mosaddegh M (2014) Ethnobotanical survey of medicinal plants used traditionally in two villages of Hamedan, Iran, Research Journal of Pharmacognosy (RJP) 1(3) : pp 7-14

14. Pandhare Ramdas, Balakrishnan Sangameswaran, Mohite Popat, Khanage Shantaram (2012) Antidiabetic and antihyperlipidaemic potential of Amaranthus viridis (L.) Merr. in streptozotocin induced diabetic rats, Asian Pacific Journal of Tropical Disease, S180S185

15. Qureshi S J, Khan M A, Ahmad M (2008) A survey of useful medicinal plants of Abbotttabad in northern Pakistan, Trakia Journal of Sciences, Vol. 6, no. 4, pp 39-51

16. Rahman Mahbubur A H M, Mosharof Hossain M, Rafiul Islam A K M (2014) Taxonomy and Medicinal Uses of Angiosperm Weeds in the Wheat Field of Rajshahi, Bangladesh, Frontiers of Biological and Life Sciences, 2(1): pp 8-11 DOI: 10.12966/fbls.03.03.2014

17. Sârbu I, Ștefan N, Oprea A (2013) Plante vasculare din Romania. Determinator ilustrat de teren, Edit. Victor B Victor, București

18. Schippman U, Leaman J Danna, Cunningham A B (2002) Impact of cultivation and Gathering of Medicinal Plants on Biodiversity: Global Trends and Issue, FAO 2002, Biodiversity and the Ecosystem Approach in Agriculture, Forestry and Fisheries. Satellite Event on the occasion of the Ninth Regular Session of the Commision on Genetic Resources for Food and Agriculture. Rome, pp 12-13 
19. Semwal DP, Saradhi P Pardha, Kala CP, Sajwan BS (2010) Medicinal plants used by local Vaidyas in Ukhimath block, Uttarakhand, Indian Journal of Traditional Knowledge, Vol 9 (3), pp 480-485

20. Vitalini Sara, Tomèa Franca, Fico Gelsomina (2009) Traditional uses of medicinal plants in Valvestino (Italy),
Journal of Ethnopharmacology 121 (2009) pp106-116

21. WHO (1987). Global Medium-Term Programme (Traditional Medicine) covering a specific period 1990-1995. (WHO document TRM/MTP/87.1) 